\title{
The Instability of Political and Administrative Institutions in the Democratic Republic of the Congo
}

\author{
Chelo Kpats Guyguy*, Xiaojun Xu \\ College of Sociology, Central China Normal University, Wuhan, China \\ Email: ^guyguy.chelokpats@yahoo.com
}

How to cite this paper: Guyguy, C.K. and Xu, X.J. (2019) The Instability of Political and Administrative Institutions in the Democratic Republic of the Congo. Open Journal of Social Sciences, 7, 53-84. https://doi.org/10.4236/jss.2019.72005

Received: March 27, 2018

Accepted: January 29, 2019

Published: February 2, 2019

Copyright $(9) 2019$ by author(s) and Scientific Research Publishing Inc. This work is licensed under the Creative Commons Attribution International License (CC BY 4.0).

http://creativecommons.org/licenses/by/4.0/

c) (7) Open Access

\begin{abstract}
This article uses a historical approach to identify and analyze the factors leading to the instability of political and administrative institutions of the Democratic Republic of Congo from independence to the year 2017. There are multiple factors related to institutional instability in the DRC. Key among them includes the inadequate constitutional provisions, the difficulties caused by the non-application of democratic principles, the heterogeneity of the populace and frequent conflicts. Other contributors to the institutional instability experienced in the DRC include the politicization of the administration, the prevailing social-economic situation, poor governance, the non-observance of the laws, the poor distribution of the national wealth, foreign pressures and macroeconomic influences. The challenges due to institutional and political instability in the DRC provide opportunities for the Congolese state and its populace to re-invent itself to be a truly democratic space where the ambitions to develop and improve the living conditions of the people can be improved through stabilized and functional institutions.
\end{abstract}

\section{Keywords}

Instability, DRC, Political, Administrative, Institutions

\section{Introduction}

This study focuses on the chronic instability of the political and administrative institutions of the Democratic Republic of the Congo covering the period from independence from 30 June 1960 until 2017.

Today, the Democratic Republic of the Congo remains confronted with difficulties of all kinds. For more than a decade, there have been endless wars and conflicts with rapes, deaths among civilian populations, internal and external displaced persons, looting of resources, insecurity of people and their property in the Territory National. The DRC has subsequently undergone very important events, 
the most recent of which (1998-2004) are politico-economic-military, presented in the form of civil wars. Following the movement leading to its independence on 30 June 1960, the Republic saw the birth of the political parties on the one based on nationalism, others on the quest for money.

Indeed, the crisis in the Democratic Republic of the Congo affects the entire population and in a very special way the political and administrative institutions of the Democratic Republic of the Congo. However, the political institution of the DRC is constituted by the Government, the National Assembly, the Senate as well as the political parties. And, the administrative institution is composed of general secretariats: the different directorates, the provincial ministries including the territorial where corruption gangrenes, the non-mechanization and the bad payment of the agents of the administration Public of the DRC.

On the other hand, the causes we have identified are not exhaustive. Nevertheless, we believe that we have studied those that promote instability, and we feel, without fear of a great deal of deceit, that they are fundamental.

\section{Literature Review}

As Bwendelele points out $(1968,12)[1]$, we are going to talk about the internal causes that are the first factors in political and administrative instability, and then we have analyzed the external causes that, in developing countries, are playing a Crucial role in the frequent changes in government Institutions. Among the internal causes, we have studied institutional causes, liberal or parliamentary democracy and its consequences on the stability of Institutions, ethnic heterogeneity (especially when it is poorly managed). There is also the politicization of public administration, the social-economic situation, poor governance, the non-observance of texts and the poor distribution of wealth.

External causes include international geopolitics, the absence of powerful lobbying that negotiates the interests of the DRC at the international level and the international policy of predation on the wealth of the DRC Lead to the extent to which the influence of foreign nations, multinationals and the struggles between the major powers can undermine political stability in the Democratic Republic of the Congo.

On the other hand, the Lusaka agreement of July 1999, unanimously presented by peacemakers as the unavoidable way of exiting the crisis for the Democratic Republic of the Congo and the countries of Great Lakes Africa in general, is placed in a Context to be remembered Willame, J. C., (2007, 15) [2]. To understand this article, we used the historical approach to gather, analyze, compare, and criticize the facts relating to this work.

\section{Discussion}

\subsection{Internal Causes}

In order to explain the instability of the political and administrative Institutions of the DRC, it is important to study the internal causes which we believe are fundamental before we see to what extent foreign pressures are involved. 
These causes are many. They cannot, therefore, be full. Nevertheless, we have selected some of them that we considered important: the inadequacy of the constitutions to the reality in the DRC, ethnic heterogeneity, the politicization of Administration, socio-economic situation, poor governance, Non-observance of the texts and the poor distribution of wealth. We have examined each of these causes to highlight the instability of political Institutions.

\section{1) Constitutional Inadequacies}

When one studies the political Institutions of the African countries, one is soon struck by the inadequate nature of the constitutions of these states. These are generally modeled on the constitutions of old metropolises, without taking into account the particular situations of each country.

How do we want constitutional provisions to be developed for a highly industrialized country, for a people with better social conditions, to be applied to a developing country? How is it possible that a Constitution made for a people accustomed to the mechanism of democracy can be, without development, applied to a population whose traditional organization does not know the separation of powers, fundamental principle of democracy?

Such a transposition can only be fraught with enormous difficulties and therefore create instability in the Institutions, so it is rare for the Constitution to be altered. And, if it is, it is for imperative reasons and with broad support from the public, because it is an agreement, a social contract or a convention that the people give themselves to live together and be directed. The good Constitution ensures unity, peace, love, solidarity, justice, and well-being. A bad Constitution carries the germs of disunity, ethnic conflicts, corruption, tyranny, impunity, poverty, disease, mismanagement, violence and the disintegration of the Nation (UNDP, 2004) [3].

Let's note for example:

a) The civil war that marked the country, from 1960 to 1963 , including the secessions of Katanga and South Kasai.

b) Armed insurrections and armed conflicts. The Muralists insurrections from 1963 to 1965 had affected three-quarters of the country. Under the Second Republic, the regime of President Mobutu was faced with armed rebellions in 1967, in 1977 , in 1978, ...before falling under the blows of that of 1996-1997.

c) The social movements of strikes and protest, in particular, the major movements of students, In 1969, In 1971, In 1986 and In 1990; The great strikes of civil servants and teachers who ended up breaking the illusion of tranquility that reigned during the Second Republic.

The resistance against the dictatorship of Mrs. Joseph Désiré Mobutu and Laurent Désiré Kabila, including the student movement, the letter of the 13 parliamentarians and the market of Christians on February 16, 1992. The popular resistance against foreign aggression of Rwanda and Uganda and the new form of dictatorship internal tending to establish the Balkanization. This form is especially by Mgr. KATALIKO and civil society... 
To date, the Government of Joseph Kabila, creating a crisis and this crisis is responsible for the eradication of the evil that gangrene of the DRC by contempt of text and the bottleneck in the process people election. This chronic state crisis prompts us to explore in depth the causes of inadequate institutional instability in the constitutions of these States which has also deeply affected the Congolese economy (Kibanda, M., et al., 2005, 44) [4].

As for the fundamental principle of democracy, it is defined as the Government of the people, by the people and for the people. The practice of democracy must be learned. It depends on the will and determination as well as the collective wisdom of the peoples themselves and not the benevolence of the leaders who only derive their legitimacy from themselves. Democracy is not just a set of rules and constitutional procedures that determine how a government works, but it is also a system of government that is seen as part of a social fabric made up of institutions Public and State, political parties, organizations and associations of numerous and diverse.

This diversity or pluralism implies that the multiple institutions and governments organized within a democratic society do not depend on the government for their existence, their legitimacy or their authority. They interact with the Government, motor and responsible for the collective life. Indeed, democracy is emerging through the complex ensemble of political, social, religious and cultural forces at work in a community. Economic development paves the way for democracy and political will makes it a reality. It does not go back to the sum of the institutions. Any healthy democracy depends largely on the behaviors, practices, and norms that determine the ability of people to govern themselves. It requires a civic culture (Op. cit. 2005; 14, 19.38).

The DRC should open up an era of freedom and development. But, the proclamation of independence on June 30, 1960, brought the Congo into the zone of political turbulence where Prime Minister Patrice Emery's speech Lumumba pronounced that day will throw the cold in relations between the Congo and the former power Colonial. Very soon, the relationship between President Joseph KASA-VUBU and the prime minister will be spoiled. In September 1960, they will revoke each other.

The latter, also calling for the Constitution and the democratic principle which wants a government with a parliamentary majority to remain in place, would not want to submit to the presidential decision. Thus, the crisis began and, for five years, the Democratic Republic of the Congo will not have the stability of political and administrative Institutions. It was in the face of this confusion that Colonel Joseph Désiré Mobutu made a first "coup d'état" and set up the College of Commissioners General (Léon de Saint Moulin et al., 2003) [5].

As of 17 January 1961, the assassination of Patrice Lumumba, Joseph Okito and Maurice Mpolo will be the death knell for the confusion that is to come and will continue, despite the interlude of the Adoula government, until Mobutu's seizure of power on 24 November 1965. 
The regime established by Mobutu will be characterized by authoritarianism, single partyism, less consideration of human rights. The living conditions of the population will deteriorate as we go along. The population will thus implement survival strategies. Deceptive and deceptive slogans such as "Moto $\mathrm{Na}$ moto Abongisa", "MPR equals serve, serve, no" and the Philosophy of "authenticity" will only maneuver to seat the party-state (Kibanda, M., et al., 2005, 4).

The democratization launched on 24 April 1990 will only be a powder in the eyes. The immense hope raised by the secular community at a Sovereign National Conference (C.N.S./Narine Simonian), from August 1991 to December 1992, will be short-lived. The transition that begins will be an uninterrupted sequence of disappointments. On these Entreaties, comes to power on May 1st, 1997, the Alliance of Democratic Forces for the Liberation "AFDL" of Laurent Désiré Kabila who overthrow the dictator weakened by a long popular protest.

One year later, a series of rebellion movements based on the lack of democracy for some, sometimes on the looting of natural resources and thus of the economy (appropriation of mining and natural resources). This wave of wars proved to be extremely complex, splashing the entire Great Lakes region and making more than 3 million deaths.

On 4 August 1998, the so-called "first African Continental war" of Rwandan, Ugandan and Banyamulenge (Congolese Tutsi in Kivu) troops, commanded by a Rwandan general, James Kabarege, also chief of the military staff Congolese since the takeover of Laurent-Désiré Kabila will enter Zaire. In the aftermath, these troops took over a daring airborne operation, from Goma in North Kivu, of three airliners at the base of Kitona. During the next two weeks, an aerial bridge is established between Kigali and Kitona and allows the delivery of several hundred Rwandan soldiers to the DRC. It will take the contribution of Zimbabwean and Angolan soldiers, who came hastily to the rescue of the Congolese president, to loosen the vice that threatens the capital.

If, in the end, Kinshasa is not taken by the Rwandans, almost half of the Congolese territory-the eastern Province, South Kivu, North Kivu, Kivu-Maniema and part of North Katanga-is soon in the hands of rebel groups allied with Uganda On the one hand (MLC by Jean-Pierre Bemba, son of the Congolese magnate Bemba Saolona), in Rwanda on the other hand (RCD-Goma piloted by Congolese, Tutsi or Hutu "Rwandophone").

In the case of Rwanda and Uganda, it is not an alleged right of prosecution (never invoked in international legal fora) against Ugandan and Rwandan armed gangs sheltered in sanctuaries at the eastern borders of the DRC which is the cause of this "sponsorship" of Presidents Museveni and Kagame, but the natural resources of eastern DRC that excite the lusts-and rivalries-of the two tropical countries, in particular (Willame, J. C., 2007, 15-16).

It should also be noted that the allies of the DRC-Zimbabwe and Angola-have strong interests too in this ungoverned Congo, which is a "geological scandal" attracting speculators of all fur: the first covet the rich diamond deposits of Kasai 
and the mining resources of Katanga, including the Gécamines, a bankrupt mining company, which owns the exploitation rights; The second is the offshore oil off the Congolese coast.

While during this time of violence, armed gangs and warlords settle in the DRC, diplomatic negotiations are carried out everywhere and at all levels. The initiatives emanate from SADC, the African Union, Zambia, South Africa, France, Italy (through the abortive mediation attempt of the Saint' Egidio community), Chad or even Colonel Gaddafi's Libya. They will eventually lead to Lukasa on 10 July 1999 where, after many procrastination and resumptions of hostilities by the belligerents, whether they are warlords or representatives of heads of State, a ceasefire agreement is signed by the governments Congolese, Namibian, Rwandan, Ugandan, Zimbabwean, Angolan, as well as by the MLC and RCD rebels, who control the east of the country. But this agreement will remain a long-term agreement on paper.

One of the main obstacles to the culmination of a negotiated agreement (and its subsequent stalemate) is first in the personality of the Congolese president, Laurent-Désiré Kabila. According to his biographer, Erik Kennes, the new self-proclaimed head of state of the DRC is above all the man of a bygone era with whom he has never been able to break.

Still clinging to his experience of "Maquisard" of the years" 60 pursuing the old nationalist dream of Patrice Lumumba, he led, with some former companions of road, a fight from the outside, a popular struggle disconnected from the process of change Policy-induced by a large fraction of Congolese civil society and the Sovereign National Conference of the years' 90.

Still, according to Kennes, Laurent Désiré Kabila presents himself as an exclusive source of reason. It discards from a reverse of the hand, in the name of the national reconstruction and the creation of a new society, the political parties "who are all Mobutuist" and the civil society that is "sold Abroad". Everything is to be done again, all the Congolese are sick of the Mobutism that Kabila will want to heal with a limited team largely from a Congolese diaspora, sometimes vengeful and frustrated.

Kabila is also, in his own way, a warlord, but in the revolutionary and "Maoist" tradition of the years' 60. It has thus integrated into the new Congolese Armed Forces (FAC), rid of the Mobutuist, of Mayi-Mayi military leaders from its former Maquis.

And then, Laurent-Désiré Kabila is an obstinate "refusenik". From the beginning of the presidency, note Kennes, he attacked all fronts at the same time. Against the west, against hostile African countries, against political parties, against civil society, against large foreign companies... One wonders whether, for the sake of efficiency, he should not have proceeded with small steps, given the diplomatic and military weakness of his regime, and recreate, with the cunning that he has sometimes been recognized, a real current of resistance against the omnipresent interests Foreigners". 
Amazing repetition of history? He appeared much like Patrice Lumumba in July 1960, who also fought on all fronts: against Belgium, against the United Nations, and even against the African nationalist leaders who are, however, in principle on his side (Willame, J. C., 2007, 16-18). Like a Lumumba trained at the Africanist and Anticolonial School of the years' 60, Kabila was a part of the Antimobutiste and anglophone "Tanzanian school", such as Presidents Museveni in Uganda, Kagame in Rwanda, Mandela and Thabo Mbeki in South Africa, Mugabe in Zimbabwe, and Dos Santos in Angola. But came to power, he broke up with some of his friends, the most influential on the world and African scene, including the first four, who became his enemies.

Obsessed with the restoration of a great nationalist and anti-imperialist Congo when he did not have the means of his dream, autocrat, who loved absolute power and feared conspiracies like Mobutu, he quickly isolated internationally before Refuge in a sort of bunker from which he only came out with armed escorts to the teeth.

Inpatient and refusing any temporary compromise, he quickly dug his own grave especially as the majority of Congolese considered him a "stranger" who had lived, with his friends, far from the "Zairian experience".

In the West, it loses all credibility, except in very small ideological cenacles active in the United States (Ross and Green Lobby) and in Belgium (European Forum for a north-south generation contract, Belgian Labour Party), two countries that still feel More or less concerned by developments in the Congo since the cancellation of the Troika (USA-France-Belgium) at the end of the Mobutu regime.

Subsequently, the assassination of Laurent Désiré Kabila on 16 January 2001, which will put an end to authoritarian power. The latter will be succeeded by his son and mark the beginning of a new era leading from inter-Congolese dialogue to a fragile peace process and a slow transitional government (Kibanda, M., et al., 2005, 4-5).

Tixier, Georges., $(1996,117)[6]$, states that the same situation also occurred in Senegal, where the conflict pitted the head of State against the head of the government: President Léopold SEDAR SENGHOR ousted his prime minister MAMADOU-DIA and the conflict between the branches of the executive would not leave the political and administrative Institutions stable in that country.

Let us say that the question of the wealth of the Congo covers the whole history and still poses today the problem of the model of development and the mode of governance that should ensure lasting peace on this space.

Let us also underline the fact that some models of development are copied without taking into account our realities, others are imposed by the Western powers and still, others are tailored to perpetuate the reign of dictators.

\section{2) Parliamentary Democracy and its Consequences}

Reflecting on the application of liberal democracy in Asia, Tan-Van, MINH $(1964,3)$ [7], wondered whether this regime was suitable for a changing society, a transition society. In fact, when we go back to the past, we see that already Aristo- 
tle regarded the transition phases as favorable to tyranny especially during the transition from a patriarchal society to the Commercial Society.

For Gazier $(1961,147)$ [8], the same phenomenon was renewed in modern times when men such as CROMWELL and BONAPARTE marked the passage between societies of the former monarchic, inegalitarian, feudal and new democratic societies, Egalitarian, commercial and industrial.

It is necessary to examine a point intimately linked to the notion of "parliamentary democracy" before analyzing the content of the concept. In general, it can be identified in the following way: The British parliamentary system was chosen as a model on the eve of the revolution tending towards the regime of monarchic parliamentary democracy in 1932.

Since colonial times, the Democratic Republic of the Congo has been practicing the Western game arbitrated by the parliamentary majority and the separation of power. Yet this combination is far from being a success because of a significantly different cultural climate. A major problem facing the Congolese parliamentary system, like the other countries of the same regime, is that of legislative and executive power bloc. Here, this problem has a more serious impact when one is in a context of corruption, exploitation, impunity, muzzling of opinion by misinformation and intoxication, having given rise to a new form of slavery and Causing a dysfunction of the entire democratic political system.

In the last ten years, the application of the Constitution or the act of seizure of Power by AFDL in 1997 does not bring a major change in the political life of the country. Thus, some new techniques of counter-power have been regularly exercised, for example, the referral to the Constitutional Council and the control of elections by the Electoral Commission. But it seems that a large part of the people does not really understand what is meant by democratic values. Add to this corruption, tribalism, nepotism etc. that always play a crucial role in practice at all political levels.

Parliamentary democracy is a form of modern democracy. It is often accompanied by representative democracy (also called indirect democracy) as opposed to direct democracy. This form of democracy relies as its name implies on the main institution, the Parliament, composed of elected representatives of the people, i.e. citizens. Parliament makes the law (legislative power) and eventually elects the government (executive power). This is the most common type of democracy in the world today. Parliamentary democracy is not necessarily in opposition to direct democracy. ${ }^{1}$

Among the pillars of parliamentary democracy, the principle of separation of powers is classified in the first place. This principle of separation of powers assumes, roughly, that there are powers which are exclusively the responsibility of the legislator, the executive, and the judiciary.

That is why PERICLES, already in its time, had sounded the alarm, as to the risks of democracy in societies dominated by the uneducated, the illiterate. In adhttps://fr.wikipedia.org/wiki/D\%C3\%A9mocratie parlementaire 
dition, the quality of Congolese parliamentarians is often lacking. For, some do not know the work of a parliamentarian and believe that his work is limited to deciding for or against the adoption of text or seeking to enrich itself by provoking motions to be bribed by ministers who are afraid of Lose their armchairs.

\section{3) Ethnic Heterogeneity}

Buchman, J., (1962, 27) [9], analyzing the phenomenon of ethnic fragmentation in black Africa is expressed in these words: "To talk about the heterogeneity of Negro-African society is to raise the issue of polytheism". The heterogeneous structure of the infinitely fragmented ethnic groups of the black continent is the fundamental factor in the instability of the administrative political Institutions.

Ethnic heterogeneity has become a weapon used by politicians who start manipulating ethnic groups for their selfish interests. They stand against each other. The examples confirming the facts are not lacking: the struggles between the Tutsi and Hutu in the east of the country, the integration of the Banyamulenge community as well as the recurrent conflict situation between the Hema and the Lendu people in Ituri, the struggles between the Lulua and the Luba in the Kasai including the reign of Kamwina-Nsapu prove these allegations. All of these conflicts are caused by the land problem between the communities.

The case of the integration of Banyamulenge and their cohabitation with the rest of the national community has, of course, caused the crisis within the Institutions of the country, has even led the loss in human lives on the one hand, but also the change on the other hand where Opposition actors are not considered to be the transformers of their societies. Why they failed to federate around a single organization until the end of their mandate.

Some, opportunists, who do everything to exercise and retain power as long as possible; and others criticize and conduct actions to recover or snatch power in the hands of the majority. However, they do so in scattered order. Thus, the DRC is experiencing a huge destabilization, several dialogues are organized. All this have the objective of seeking at all costs to remain in power.

\section{4) The Politicisation of the Administration}

Politicization is the action by which political significance is given to a situation that is lacking (Benoit, 1981) [10]. In Marxist doctrine, it is a fact of giving a political conscience to individuals instead of unorganized and exploited workers. It is a universal phenomenon used even in the DRC during the eve of democracy. The plethora of incompetent staff is due to the too hasty Africanization of executives and the politicization of the administrative apparatus. It resulted in high mobility of civil servants and commitments dictated by either ethnic or political affiliation.

On the incompetence and Africanization of executives, Senghor $(1961,130)$ [11], averred "Africanizing at a discount, by placing incompetent officials in positions that require a proven technicality, it is to go back, it is to introduce anarchy, waste, and inefficiency in the services of the state, it is to deprive us of means of a modern state". For him, the development of Africa, it is necessary that the Africans put themselves around concentric circles with a united culture, thus the ne- 
gritude.

Politicization is the action by which political significance is given to a situation without it Benoit, J., (1981). In Marxist doctrine, it is the fact of giving a political conscience to individuals or rather to unorganized and exploited workers. It is a universal phenomenon used even in the countries of the Watch democracy. The plethora of incompetent staff is due to the too hasty Africanization of executives and the politicization of the administrative apparatus. It results in too much mobility of civil servants and commitments dictated by either ethnic or political affiliation.

Speaking of the incompetence and Africanization of executives, Senghor, L.S., (1961, 130), said: "Africanize at a discount, by placing incompetent officials has positions that require a proven technicality, it is to go back, it is to introduce Anarchy, wastefulness, and inefficiency in the services of the state deprive us of the means of a modern state. For him, to achieve the development of Africa, it is necessary that the Africans put themselves around concentric circles with as field culture, thus the Negritude.

The history of Congo reminds us that the Congolese public Administration has been politicized since colonial times Campenhoudt, L., (1995) [12]. This continued after independence, that is when the management of the public thing is entrusted to the Congolese. The departure of the Belgians left the trial and error in the Congolese public Administration. Quite simply, because the Belgians did not prepare the Congolese well to take over the management of the country. The level of education remained very low, it was necessary to add to this deficit, the tribalization and the politicization of the administration which did not bring the country to a development administration.

In the end, the politicization of the Congolese public Administration is not new, it is a long time. The Congo has been characterized by misappropriation of public funds, tribalism, nepotism, corruption, and impunity. The establishment of actors under the guise of political umbrellas, stemming from the origin, obedience and political inclination, create an authoritarian state with politicized institutions.

The Second Republic was not spared by this practice in which the public service was under the influence of politics. Political authorities are mixing in administrative matters, although the Public Administration is the implementing body for political decisions. In no case can these decisions be influenced by the policy of the.

Like any administration, the Congolese public administration should pursue the same missions, those of general interest. The facilitators of this body seem to be akin to politics whereas, in relation to the neutrality of the Public Administration, the administrative behavior had to be any other.

The transitional period allows us to make a bridge between the second Republic and the third, and this transition with the second Republic will see their end in February 2006 with the promulgation of the new constitution to govern the $3^{\text {rd }}$ Republic.

Hence, all these elements-lack of competent staff, the politicization of Admin- 
istration promote the imbalance and instability of political and administrative Institutions. This is how we find that there is no change in its evolution, although there has been an establishment of the apparently democratic political institutions. Rather, we are witnessing a kind of advanced decay of the Congolese administrative system, the proliferation of anti-values, an administrative system characterized by corruption, impunity, the hijacking, clientelism, nepotism, and Subjectivization of its human resources. Let's add that there are 250,000 eligible pensioners to whom the state is not even able to pay the exit allowances.

\section{5) Social and Economic Causes}

Since 1885 to date, the Congo has gone through several types of anachronistic situations (economic exploitation and despoilment, discrimination of Rights, slavery, repression, segregation, political fascism, The irresponsibility of the citizens, the non-respect: of human rights, the heritage of power to put an end to barbarism or the colonial State and today to the situation of non-state). Different governments have adopted schemes such as anarchism, authoritarianism, and pluralism according to the different modalities of design and management of state power (Kibanda, M., et al., 2005, 27-28).

The collapse of the Congolese State was mainly due to proxy wars, to the moral and political inability of the elite to manage the public thing, to the dictates that created political crimes (constitutions, political systems, modes of Management), in short of realities and violence... and mortgaged independence and national sovereignty. The struggle for development, the construction of the state appears as a new challenge to be faced.

At the time of independence, both Congolese and foreigners considered that the State had a major role to play in promoting economic and social development. Until the middle of the decade 1970, many things were achieved in the social and economic fields. After this period, the results have declined constantly: many social gains have suffered severe erosion (a profound failure of policies, Divestment, and deindustrialization) (Op. cit., 28-29).

The causes of this targeted erosion are both internal and external, namely:

a) The absence of political consensus: the ineffective intervention of the military and the wrong direction (lack of probity, fairness, responsibility and patriotism, obscurantism;

b) Poor design of credible and sustainable priorities and policies resulting in a shortage of administrative and financial capacity due to rural exodus or brain drain and poor living and working conditions;

c) Lack of adequate technologies;

d) The neocolonialism: domination of the former colonies by playing on internal disputes and economic practices that led to the impoverishment of populations through pre-bands for the benefit of a minority (concessions, the heavy burden of Debt, the injustice of the international economic order, the triangular trade...);

e) The lack of a dialectical relationship between the centralized state and civil society. The state has ceased to be the engine of development but rather the udder 
of predation resulting in the marginalization of the Congo, effritant the legitimacy of the leaders and diminishing the capacity of the government.

The Democratic Republic of the Congo experienced a partition of fact: with four territories with administrations (territorial and fiscal, and authoritarian armies of each other (accompanied by several militias)... The current political chaos is chronologically associated with the liberalization of the activity of political parties towards the years 1990 .

Indeed, since 1975, the DRC has experienced an economic crisis that has continued to increase. The gross domestic product (GDP), for example, has experienced negative growth rates over the entire decade of $90:-6.6 \%$ in 1990 is- $14 \%$ in 1999 (UNDP, 2001)... This economic counter-performance results from or is accompanied by several ills: hyperinflation, drastic decline in production and investment, monetary instability, weakness in budgetary revenue, public finances disorder, Deterioration of public infrastructure, including roads, degradation of knowledge and skills of human resources, the collapse of agricultural production (SNU, 2001). All macroeconomic indicators show that the situation continued to worsen until 2001, although a slight improvement has been observed since 1998 .

Of course, the failure of the country's economy and political turmoil has led to the deterioration of the living conditions of Congolese populations. Thus, the $\mathrm{Hu}-$ man Development Index (HDI) is experiencing a decline of $1.7 \%$ per annum on average since 1990. It is estimated at 0.455 in 1998 and ranks R.D. C among the world's poorest countries (UNDP, Op. cit). The purchasing power of the population, measured in terms of actual wages, represented only $1.7 \%$ of the normal level of wages for the office of the most senior public Administration.

This poverty is at the root of, among other things, the precariousness and vulnerability or fragility of the social fabric in Congo because it has a direct impact on malnutrition, health, illiteracy, infant and juvenile mortality, Risk maternity, poor habitat...

A member of the Belgian Colony Chamber Bethume (2008) [13] said that agricultural policy was defined as the main source of national wealth, and was the most important factor in the country's prosperity and economic development.

The Democratic Republic of the Congo is a country endowed with incredible wealth, not only thanks to the resources that abound in its subsoil but also thanks to its vast tracts of arable land and its immense forests that have unrivaled potential Tollens, P., ( 2009, 34) [14].

Production has been reduced in recent years to subsistence activities, despite favorable natural conditions around $97 \%$ of arable land benefiting from a crop season of more than eight months in the year.

The economy of the Democratic Republic of the Congo would be one of the least competitive economies in Africa, with the DRC being part of the LDCs ranked in 2006 among the 10 poorest countries in the world. Its economic situation is comparable to that of other Central African countries, but its economy is handicapped by a civil War creeping Bethume $(2008,128)$. 
Certainly, the Congo is a country with an agricultural vocation that could spontaneously give the riches of the products, in this case, palm oil, coffee, cocoa, cassava, maize, tea, etc. But its development requires serious capital. Agricultural policy should be the predominant concern of the Democratic Republic of the Congo to ensure conditions conducive to administrative and individual activity.

In addition, agricultural decentralization in the DRC establishes strategies for their production sectors, namely: cassava, rice, maize, coffee, Palm tree... et to take care of transport infrastructure, processing, and marketing of these products. The real function of decentralization is to enable the peasant community to live in peace, by seeking their own agricultural sectors in order to increase the budget or economy of the DRC (Ministry of Agriculture, Kinshasa, 2009, 80) [15].

Tollens, P., (Op. cit, 2009, 34), talks about the poor infrastructure and the dislocation of agricultural production sectors have blocked the economic growth of the DRC, the local food production falling well below the demand of the population Country's growing. Food insecurity is explained by the collapse of the agricultural sector as a result of the incoherence of agricultural and development policies and the dysfunction of sectors and management structures.

In the Democratic Republic of the Congo, rural populations are experiencing an unattractive economic and social situation Wembi, A., (1980, 78) [16]. As for the inhabitants of the cities, who enjoy a salary, they are affected by the austerity measures decided by the Governments and most, both in urban and rural areas, do not have access to appropriate health care, for lack Infrastructure and especially because of the lack of means by increasing the cost of living.

Concerned about the cost of living, workers' organizations are called upon to negotiate with the government. In many cases, trade unions are a formidable force that puts institutions at risk as a result of the strikes they raise to demand the regularization and increase of their wage situation.

From the end of the years 1990, another ingredient has been added to make the region a powder keg: The discovery of highly coveted ores used in the electronic industry as well as a series of other valuable natural resources such as coltan and cassiterite (tin oxide ore) in North Kivu, Ituri Gold and South Kivu, and Tropical woods, charcoal, meat, tea, quinine and papain. Militias and armies have been eager to exercise their grip on the major mining sites they have fired and continue to draw very large sums.

Over the past ten years, Coltan has occupied the main stage of all mining speculation in parallel with the mobile phone boom, which is one of the essential components. This coltan has created its lot of new rich internally as external, and especially its millions of innocent victims. It has, like the diamond in Angola and Sierra Leone, and like oil in Iraq and Kuwait, makes the misfortune of the populations whose future has been heavily mortgaged (African studies; April 2010).

Let us say that this is a Congolese society affected by a profound political, economic and social crisis which must face the constraints linked to the restructuring of the world economy into a single free market and to the global competition be- 
tween States and the new political and cultural order that is being put in place. However, the current economic situation depends, first and foremost, on the awareness of Congolese decision-makers, of being able to give good directives and economic policies; Agricultural policy, decentralization of it. Because all development is primarily endogenous and intelligence is first interpreted as the art of knowing what will serve to be successful, to conquer markets.

Instability is in a totally frozen sense, especially because its persistence is desired by many actors. Rwanda and Uganda, in particular, have an interest in the conflict as it facilitates the smuggling of ore at the border. Thus, in the east of the DRC, and particularly in Kivu, there are clashes that allow Rwanda to continue to plunder the mineral wealth and natural resources of the areas they controlled.

\section{6) Poor Governance}

Bad governance is the plague that prevents the DRC from taking off. There are looting of resources, embezzlement, corruption, financial mismanagement, the primacy of selfish interests at the expense of the general interest, etc.

For several months, the DRC has again been in bad governance, following the regime's refusal to abide by the Constitution of the country and to organize the elections without the current head of State whose second and last term has expired since 19 December 2016. ${ }^{2}$ Since February 18, 2006, President Joseph Kabila has invested the destruction to disarticulate the 2016 election organizations while we compromise in December 2017 election process.

M. Assogba deplores the unsavory behavior of some of the political leaders who seek at all costs to remain in power through truncated elections. The squandering of potentials reduces the continent to a "poverty nest", he said.

He felt that poor financial and electoral governance constituted a serious obstacle to the development of the African continent. "Corruption on the African continent is detrimental to objectivity, justice, and equal opportunities, fairness, and non-discrimination, which underlie human rights," he lamented.

Politically, it points out that corruption puts democracy and good governance at a bad level. "In the elections and in the legislatures, corruption reduces responsibility and representation in the development of policy if it is not controlled and in the judicial system it erodes the rule of law," he observed.

He has been involved in observing the elections in Africa. The African continent has been politically liberalized since the late 1980 and early 1990, following the wind of democratization that has blown over the world. "Almost all of the 53 Member States of the African Union (AU) has adopted the multi-stakeholder democracy that has led to a march towards regular pluralistic elections where competition prevails," he recalled.

In the Face of this reality, the causes for adopting this democracy are profound for the Democratic Republic of the Congo, in particular, the fact that it is a potentially wealthy country with an extremely poor population.

Bad governance still has beautiful days ahead of them. It is one of the main segments of this evil which prevents the DRC from advancing. Every time it steps ${ }^{2}$ http://www.latempete.info/24962-2/ 
forward, the country makes two in the opposite direction, backing.

Bad governance has not yet finished having hard skin. Indeed, there is a need to see how the development and mismanagement of the resources for development projects and the vitality of the Congolese have always been absent at the rendezvous of progress which is only moving away like the wind.

Moreover, fifty-seven years ago, Congolese agriculture was the most prosperous in Africa; the DRC was the largest exporter of certain tropical products such as coffee, cocoa, palm oil or rubber, with agricultural research in International reputation.

Today, Congo has been virtually wiped out of the list of exporting countries for agricultural products, despite an agricultural potential that puts it in second place as a world reserve for mechanizable arable land after Brazil, while its research Agronomics is no more than the shadow of itself. ${ }^{3}$

The Congolese manufacturing industry was the first in sub-Saharan Africa. Today it has lost whole parts to the benefit of similar products imported. Fifty years ago, a mail sent from any corner of the Republic was certain to arrive at any point of its destination.

Health coverage reached the most remote villages in the country and the health care system was one of the best in the continent to the point where South Africans came to be treated in Elisabethville/Lubumbashi, the Capital of one of the DRC's provinces.

To date, most Congolese, both in urban and rural areas, do not have access to appropriate health care because of adequate infrastructure and especially lack of resources, while South Africa has become one of the preferred destinations For all Congolese who wish to benefit from health care that meets international standards.

Fifty years ago, any parent could ensure the schooling of his offspring up to the second level with the sole income of his agricultural work, the state taking full relay at the university level with scholarships Accessible to all.

Today, the schooling of children falls under the path of the cross for most parents, including the teachers themselves, while the Congolese government scholarship is part of the exception which can only benefit a few Privileged few.

This widespread deterioration of the economic, social and moral situation of Congolese society is attributable, in large part, to the carelessness of the Congolese politician, all generations combined. This negligence took the form of many ills, including financial mismanagement, misappropriation of public funds, poor governance and corruption ${ }^{4}$.

No one is unaware that poverty in the DRC is not a myth. To be persuaded, it is sufficient to note the inability of a large majority of Congolese populations to meet food needs, inability to access health needs, access to schooling, decent housing, etc. All these facets of poverty are observable both in urban and rural environments. Poverty in Congolese society is also perceptible by increasing social phenomena that reflect a profound social crisis. The most convincing case is probably ${ }^{3}$ http://www.lecongolais.cd/la-mauvaise-gouvernance-la-corruption-et-limpunite-ont-encore-de-beauxjours-devant-elles/ 
the prostitution of minors.

In the end, we denounce the unspeakable suffering and misery that has become the daily lot of the Congolese population deprived of the emotional enjoyment of social and economic rights due to bad governance and the blatant injustices practiced by the various Congolese governments under the beard of the institution President of the Republic.

The same is the opacity surrounding the setting of salaries, emoluments, endowments, and other bonuses of the animators of the institutions, in general, and the institutions President of the Republic and Government, in particular.

To remedy bad governance first, the people must learn to sanction their political leaders by "a vote sanction", the people must come out demonstrating against all political policies carried out by governments. They would have to feel a threat to change things, we must have a mechanism to control government action other than that of Parliament because in Parliament it is always the same majority between government and the National Assembly and this elected officials of the same political party will never sanction their comrades in the government. This is often called the dictatorship of the political parties that are the real actors of bad governance.

We strongly believe that mediocre leaders are at the root of bad governance which is the key factor in the suffering of the Congolese people. They have put in place a bad policy and a bad strategy to bring the people to the suffering. This is how we mock Congolese leaders in the world. We dare to believe that one day each of the Congolese, at the forefront of the rulers, will have to divorce with bad governance and corruption; it will be a beginning of "liberation" for one and the other, even if it appears, until then, as a chimera.

\section{7) Non-compliance with the Laws}

Since its independence, on 30 June 1960, the Democratic Republic of the Congo has faced recurrent political crises, one of the fundamental causes of which is the challenge of the legitimacy of the Institutions and their facilitators. This challenge took a special relief with the wars that tore the country from 1996 to 2003 (The Constitution of the DRC, 2006, 1-78) [17].

At the same time, the non-observance of the texts and the non-internalization of the constitutional values are on the basis of historical mismanagement in the Democratic Republic of the Congo. Thus, the culture of respect for texts is the basis for the foundation of a rule of law in the world and especially in Africa. However, the President of the Congolese Union for Freedom (UCL) tells us that the Congolese must eradicate to take the most beautiful momentum as claimed in their national anthem remains the non-respect of the texts. ${ }^{5}$

He illustrated his thesis by the refusal of the first President of the Democratic Republic of the Congo, Joseph Kasa-Vubu to submit his text to the government of the time led by Patrice Emery Lumumba, thereby violating the Basic Law. The history of the DRC will then be riddled with cases of deliberate violation of the texts, thus opening the series of crises a repeat, until today.

${ }^{4}$ Idem. 
On the Belgian side, there was only one speech delivered by King Baudouin 1st, head of state, despite the presence of Prime Minister Gaston EYSKENS, head of the Belgian Government; while on the Congolese side there were two. One delivered by President KASA-VUBU, head of state, and the other unforeseen pronounced by Prime Minister LUMUMBA, head of his government who will throw the cold in relations between the Congo and the former colonial power.

Thus, the two speeches were diametrically opposed, in style as in tone, and their editorial conflict had produced disastrous consequences for the young Congolese state. These two speeches were also proof of the non-consultation between the two institutions at such a historic and solemn time for the DRC. And this, simply because according to history, on the Congolese side, there has been a lack of respect for the texts, more precisely the Basic Law of 1960.

The Basic Law of 1960, modeled on the Belgian Constitution, unfortunately, led to President KASA-VUBU, a president who reigns but, who does not govern. Therefore, as in Belgium, the speech of President KASA-VUBU should have been drafted by the Congolese government.

President KASA-VUBU had refused to submit his draft speech to the censorship of the government, violating the Constitution of the time, despite the demands of the government LUMUMBA. In turn, he will pose an unconventional act because of the non-observance of the texts. Itself also, in spite of everything, could not do so because he was not head of state.

These historical facts which constitute the original sin of the Congo from its birth are unfortunately still a tare that is perpetuated in the management of the DRC. and the non-observance of the constitutional, legal and regulatory texts, or even of international conventions duly ratified by the DRC and which have a higher authority than internal positive law, has been since the "Sacred Day" at the origin of the tensions of which have glazed the history of the Democratic Republic of the Congo and prevent it until today from functioning normally.

The Congo is, therefore, a country that cannot enforce its sovereignty, hampered by the weight of historical heritage and by regional instability. Even now, the situation is far from being stabilized, as shown by the political crisis in which the country has been plunged since Joseph Kabila's contested re-election in November 2011.

The regime's refusal to comply with the Constitution of the country and to organize the elections without the current head of State whose second and last term has expired since 19 December 2016 and the President Joseph Kabila has invested the destruction to disarticulate the 2016 election organizations while we compromise in December 2017 election process. To this end, the "business climate" is very uncertain, which does not encourage private investment in DRC.

Today, the deficit of state authority is a fact that has been established for decades and is growing: the country is poorly governed. This opens the door to anar${ }^{5}$ Read more at https://7sur7cd/new/2017/07/lokondo-fustige-le-non-respect-destexts-Depuis-1960/\#wd282bWuDECF KpkY.99. 
chy and maintains an economic, social and political climate conducive to balkanization. Indeed, the confusion is general: the structures of the state being already deficient have become, moreover, illegal, or in any case unconstitutional. Fortunately, there is the agreement of the New Year's Eve which legitimizes them until the next elections of 31 December 2017. The country is even more fragile than ever. Politically, it is exposed to all the winds ${ }^{6}$.

In plain view, in the face of such a slump, we can consider that, in the exercise of his duties towards us, our political class almost. As a primary sovereign, you must take your destiny in the peaceful and democratic ways, in the active and evangelical non-violence.

Conversely, the Democratic Republic of the Congo refuses the rule of law to borrow the pattern of the law of force, violence and the jungle. The Republic will have made the choice of the insecurity of violence, conflict, and chaos.

We have the ambition to believe that the Democratic Republic of the Congo must have the respect of the provisions by locking the system in the interest of consideration of democracy because the DRC is not in itself sick of the texts but rather it is the actor's Policies that do not want to respect the texts. Sometimes texts are respected by those who are in power only when they guarantee their interests. Whenever the texts are no longer to their advantage, they either modify them immediately, or they arrange to no longer respect them by pushing arguments detractors. In this regard, Bourdier Pierre evokes the roles of the bourgeoisie and the elite in the manufacture of laws.

\section{8) The Poor Distribution of Wealth}

The DRC, an outrageously rich country but the population lives in the darkest misery (cf. GNP, per capita income, etc.). The wealth of an individual or a country is generally expressed in terms of money and income, but also the accumulation of such assets in the form of. It is not only a state, but it is also a flow.

As noted by Yves Lacoste (1986) [18], in his book "from Geography to landscapes", he emphasizes that the environment in all its dimensions is strategic and thus, the realization of the limits of the planet's resources, It notes that its structuring leads to conflicting attitudes on the part of certain states. Those who consider any attempt to claim common as an infringement of their sovereignty. The greed aroused by the mining wealth of the DRC plunges the country into a war of resources.

It sums up that the DRC is one of the least developed countries on the planet. It also notes that all the actors involved in looting natural resources in the DRC are illegally exploiting natural resources to fuel their war effort, making it difficult to find a peaceful solution. Today, the protection of Congolese world heritage is becoming almost non-existent because the Congolese people are not able to put into practice the rules of international environmental law.

The IMF, for its part, shows that the DRC remains one of the poorest in the world, despite the immense richness of its subsoil. It calls on the Congolese gov${ }^{6}$ https://actualite.cd/2017/05/18/rdc-cinq-eveques-catholiques-denoncent-deficit-de-letat-mauvaise-gou vernance/ 
ernment to diversify its economy, among other things to create more jobs.

There is only one figure to make more of a European economy more envious. Yet despite this good score, the Congolese standard of living does not improve, or too little. Eight Congolese in ten still live on less than 1.25 dollar a day. This is much less good than most countries in the region. The Congolese economy is not diversified enough.

Its growth is mainly based on the mining sector: Cobalt, copper, and diamond. A segment that produces cash but too few jobs. Result. Unemployment remains very high, especially among young people, analysis of the IMF. ${ }^{7}$

Another problem, corruption, and armed groups or (warlords) in eastern Congo prevent a good redistribution of these riches. The fact remains that progress has been made in other areas, such as access to education and health, but not enough to achieve the Millennium Development Goals, recalls the IMF. Finally, the latest disruptive elements of the economy according to them.

According to Global Witness (2005) [19], in its report titled: "Peace under tension: Dangerous and illicit trade in the Cassiterite in the east of the DRC", shows that the DRC is a country endowed with extraordinary natural resources, but whose population has never benefited. It then notes that the DRC has been at the center of a phenomenon called "African World War".

His analyses show that the motives of this war were not only political and/or ethnic but also economic. This report then shows that the main battles such as the capture of the province of Tshopo in Kisangani, a province rich in diamonds, were motivated by the presence of natural resources.

To this end, the Democratic Republic of the Congo is a country rich in natural resources, despite the fact that its population remains in the misery that now plunges this country into poverty. A long time ago the wealth of the DRC attracted the lust of its neighbors and even Westerners. This lust has been made both internally and externally and has led to the illegal exploitation of natural resources which has had consequences for the protection of the National environment.

Indeed, although the wealth of the DRC was the object of lust, it was during the first war waged by AFDL in 1996 with Ugandan and Rwandan armies, from the eastern provinces of the country, that natural resources were looted Armies as they progressed. This looting was done, of course, and unfortunately, in complicity with the Congolese themselves.

It should be said that man was himself destructive of his own living environment. There is no doubt that first the DRC is endowed with an abundance of scarce mineral resources from the northeast to the southeast of the country (coltan, diamond, gold, copper, cobalt, zinc, manganese, etc.), forest resources and Wildlife (gorilla, Okapi, ...) very rich and Agriculture (coffee, tea, tobacco, ...). Then it is endowed with immeasurable resources to the size of its area. Thus, the DRC has long been subject to smuggling and traffic enriching internal looters, even its ruling class. It is also the object of greed and illegal exploitation of its wealth by the

${ }^{7}$ http://www.mediacongo.net/article-actualite-13414.html 
neighboring countries as well as unpublished actors sometimes difficult to identify.

This lust for the wealth of the DRC has had a detrimental impact on the protection of the national environment, whereas it is this environment that is the framework of life that ensures health, food, shelter, rest and recreation.

First, the Congo obtained its independence from Belgium in 1960, of which it was a colony from the Berlin Conference of 1885 . This period of colonization had a decisive influence on the country's current situation. The period following independence was marked by strong instability, particularly because of the separatist ambitions, supported by Belgium. (Report of the United Nations Economic Commission for Africa, 2015) [20], the situation is partially stabilized in 1965, with the arrival in power of Mobutu Sese Seko, who governs the country until 1997. But even during his reign, agitation is strong and he manages to maintain power only through coercion and division. "Thus, even the episodes of apparent peace, especially under the Mobutu regime in the years 1970 and 1980, were made possible not because of the success of a peace process, but by a crackdown on the discontent of the population," continues the Report.

Also, in October 1996 erupted an ethnic rebellion in Kivu, eastern Congo. One of the triggering factors is the questioning by the Government of the nationality of the Banyamulenge. They are Tutsis of Rwandan origin living mostly in Kivu. Their rebellion quickly placed under the leadership of Laurent Désiré Kabila. The latter was chosen by the powerful foreign sponsors of the rebellion, at the forefront of which his found Rwanda and Uganda. This support from the Congo's neighbors allows Kabila to obtain a rapid military victory over Mobutu and take power in May 1997.

But while Kabila's arrival in power was quickly and without major effort, his own disappearance was also rapid as he had broken his alliances with Rwanda and Uganda. Indeed, Kabila and obliged to take his distance from his former allies, very greedy in counterparts-notably Rwanda-and whose interference provokes the hostility of the population. Thus, Rwanda and Uganda support a new rebellion which erupts from 1998 against Kabila and which triggers the second Congo war. Kabila's regime was then rescued in extremis by the forces of Angola, Namibia and Zimbabwe, making the conflict a "great African War" (Op. cit. 2015).

On 16 January 2001, Laurent Désiré Kabila was mysteriously murdered in his official residence in Kinshasa. Two days later, it was the coronation of his son Joseph Kabila who replaced him at the head of the country and marked the beginning of a new era leading to the Lusaka Peace Agreement, signed by the belligerents (Congolese and their respective foreign allies) in July 1999, but which unfortunately will not be enough to bring peace to DRC Filip, Ritjens., (2012) [21]. The Inter-Congolese dialogue held in Sun City (South Africa) for more than two months is not going to be successful either. It took the pressure of the international community and above all the forcing of the South African and UN mediation to, first, bring the Congolese actors back to the table of negotiations and then impose 
on them the signature of the Global and Inclusive Agreement, to Pretoria.

Although the DRC is officially in peace since the Pretoria agreements of 2003, the country faces structural instability and fighting continues in the north and east of the country. Similarly, if they have long claimed to have definitively withdrawn from the country, the regional powers retain troops in the DRC (Op. cit.).

It should be noted that, contrary to the time of the Second Republic, the objectives of the foreign policy of peace were clear and defined on the basis of a stable environment. Today, these objectives are rather blurred because the geopolitical environment of the DRC is uncertain, the resources allocated to the defense of the country are less important than before. The only certainty for the DRC remains its position as a major development pole located in the heart of Africa. Thus the political climate is very uncertain after the elections of 2006, which kept Joseph Kabila in power since this still crystallizes the opposition. Political turmoil worsened more and more in DRC.

The inability of the various "ceasefires" and peace agreements to end the wars is indicative of deep-seated problems within the political classes that perpetuate antagonisms between groups, and the conflicting relations between the Democratic Republic of the Congo and its various neighboring countries.

In summary, the consequences of these armed conflicts have been reflected in the environment that provides the framework for life. And despite the potential of the Democratic Republic of the Congo, the Congolese people are still in a very agonizing situation and in great poverty. The question of the wealth of the Congo covers the whole of history and still poses the problem of development and governance to ensure a wave of lasting peace on this space.

\subsection{External Causes}

Let us recall the history of the creation of the independent State of the Congo whereby mutual agreement the Western powers declared the CIS as a free trade area. This original agreement sticks to the skin of the DRC until today, because all these powers are keen to take advantage of the wealth of the DRC. (Cf. speech by Nicolas Sarkozy where he said that the DRC should share its wealth with its neighbors). Who are his neighbors? What are the countries that surround it or the countries of the West that created it? The real neighbors seem to be the Westerners who created it, who help or destabilize it depending on whether their interests dictate them to act in any other way.

The analysis of external causes leads us, in fact, to the extent to which the influence of foreign Nations, multinationals, the struggles between the great powers can undermine the political stability of the Democratic Republic of the Congo. To this, it is necessary to add the international geopolitics, the absence of powerful lobbying that negotiates the interests of the DRC at the international level. Not to mention, the international policy of the predation of the DRC's wealth.

The Democratic Republic of the Congo is a society in deep crisis and is facing the challenges of globalization. This formula clearly defines the political, eco- 
nomic and social situation of the Congo at present internally and internationally. In fact, armed groups, rebellions accompanied by several militias and some foreign armies have restarted the national territory of the DRC by exploiting its resources. As a result, the war could be financed from the inside while promoting a war economy made up of smuggling and illegal trafficking of these resources (Labana, L.A., et al., 2006) [22].

To this end, the Democratic Republic of the Congo is among the states most affected by the insecurity that has caused and continues to suffer both human and material consequences. So the question we ask is what is the basis of the turbulence in the Democratic Republic of the Congo in particular? And what are the exogenous causes of repeat insecurity in this part of the Great Lakes countries region?

Thus, among the endogenous causes that justify the turbulence in the DRC, without fear of being contradicted, we will cite the period of disorders caused by the "massacres" of students of the University of Lubumbashi, the cessation of international cooperation Resulting from the looting (1991 and 1993), the blockade of the work of the CNS, the massacre of Christians claiming the reopening of the work of the CNS (13 February 1992), in short the effects of the blockade of the democratization process launched on 24 April 1990. The Democratic Republic of the Congo was still in the process of building or seeking a new political order. Since then, the political situation remains unstable and remains a concern (CENCO/CARTEC, 2004) [23].

Among exogenous causes, we will retain the implications of the belligerents' vital economic and geographical interests. Indeed, recent history has shown that the international trade in arms sales, as well as the abusive importation of arms by the African States, also plays a detonating role, as is the intervention of the neighboring States.

The clandestine trade in the distribution of arms in the region is a significant cause of the hegemonic will of the HEMA-TUTSI project, with the support of the major powers, multinational corporations, and some countries in the region such as Uganda and Rwanda. In the end, we will cite the Franco-American rivalries in the Great Lakes region.

In the end, the pressures of the economic world and the influence of foreign countries are generally exercised through the economy and finance. It is well known that the Democratic Republic of the Congo needs economic and financial assistance in order to undertake the development program.

Therefore, the establishment of the independent State of the Congo (1885-1908) by the king of the Belgians Leopold II, the Belgian colonization (1908-1960) and the wars of the last seven years (1996-2003), constitute an immense source of attraction of the powers and foreign lobbies. These resources of exploitation and despoilment economically, by the interest and envy they arouse, are, to a large extent, the basis of the instability which continues to characterize the Sub-region of the Great Lakes, preventing the Congolese from Enjoy their legitimate rights as sovereign people and free Nation. 
Today, the Great Lakes region is very marked by the genocide in Rwanda which has completed the destabilization after the slow fall of Mobutism in Zaire. The resolution of the Interahamwe question which has long gangrenous the region seems to have found a beginning of settlement in 2005. Coups and rebellions have become commonplace, this part of Africa has not known, for a relatively long time, the inter-State armed clashes between the countries members of the Economic Community of the Great Lakes countries.

In fact, at the end of the years 1990, studies abounded about the resurgence of conflicting relations between the DRC and the neighboring States of the African Great Lakes countries sub-region. These conflicts, of a political, diplomatic and military nature, have, according to many national and international experts, a single leading cause: access to natural resources of the Democratic Republic of the Congo.

Let's take a close look at geopolitics, which is a discipline that examines the relationship between space and politics. Indeed, the creation of a Union of Central African States, in 1968, with Chad and the Central African Republic, the creation of the Economic Community of the Great Lakes Countries (CEPGL) as well as the institution of numerous tripartite states of peace with the neighboring countries had a mindset, a different geopolitical rationalization. ${ }^{8}$

The DRC, the guardian of the geopolitical balances of the European nations of the 19th century, which despite everything was subject to limitations of sovereignty internally and externally, no longer exists, even if some spirits want to resurrect it. This context is subtly reproduced by the Nairobi Pact and its many protocols. From where we find nine neighboring countries with which it shares 9195 $\mathrm{km}^{2}$ of the area:

- In the West: The Republic of the Congo $\left(342,000 \mathrm{~km}^{2}\right)$;

- To the East: Uganda $\left(241.040 \mathrm{~km}^{2}\right)$, Rwanda $\left(26,346 \mathrm{~km}^{2}\right)$, Burundi $(27,834$

$\left.\mathrm{km}^{2}\right)$, and Tanzania $\left(945,200 \mathrm{~km}^{2}\right)$;

- In the north: the Central African Republic $\left(622,436 \mathrm{~km}^{2}\right)$ and Sodaa;

- In the South: Zambia $\left(752,614 \mathrm{~km}^{2}\right)$ and Angola $\left(1,246,700 \mathrm{~km}^{2}\right)$.

In practice, this organization put more emphasis on the safety of the heads of States that composed it despite this substantial security of the Member States; this could only foster peace between them.

Thus, after slavery, colonization, decolonization, pseudo-independence, and globalization, the world enters a new phase of geopolitics. During each of these major event changes, the black continent has been and remains the prey of industrialized societies. Hunger, bad governance, confiscation of power, non-respect for human rights, corruption and institutionalization of recurrent patronage, epidemics, wars, genocide, nepotism at the top of power and dictatorship Institutionalized are rooted in Africa under a Western protective shield, especially French. ${ }^{9}$

The Democratic wind that blew on the mainland in the early 90 has dissipated to the tail of poison under the vehemence of dictators and the attachment of settlers who have never abandoned the slave spirit, leaving Ashes, systems, and ${ }^{8}$ https://www.google.com/ Publié par Obed Afficher le blog le 6 Mai 2010 à 10 h41. 
methods of secular civilization. Since the colonial periods, the African continent has been glazed by the Western secret services, especially French. Since then, the social, political, economic and cultural existence of the black continent is made and defeated in the West especially in the African cell of the Elysee. ${ }^{10}$

In the light of the above, internal political crises have seen the system of the single parties exhausted but also the collapse of the east-west blocs, which in some way protected this one-party military system. The economic crisis: the fall in coffee and tea prices, including the combined effects of IMF and World Bank structural adjustment policies (massive unemployment of former government officials) have created social tensions that the claims of the multiparty were more insistent in the face of regimes that did not want to unleash their power. ${ }^{11}$

In this context of mutation, several conflicts related to nationality, identity, land tensions, the return of refugees or access to power have been instrumentalized to degenerate into more or less circumscribed or widespread massacres. But until the first half of the years 1990, each country was confronted with its own problems. There were the geopolitical vacuum and the search for regional leadership. Until the beginning of the years 1990, the regional balance was somehow guaranteed by the leadership of Zairian President Mobutu.

Nevertheless, the latter weakened from the inside by the opposition and, from the outside, by a series of international sanctions and by the loss of the support he enjoyed with the Western powers, had lost that authority. Therefore, this vacant place was to be occupied. Thus, "New African leaders", to use the words of President Bill Clinton, were to be promoted. The latter referred to presidents MUSEVENI in Uganda, Isaias AFEWORKI in Eritrea and Paul KAGAME in Rwanda and to Ethiopian Prime Minister Meles ZENAWI. In the Great Lakes region, two presidents belonged to this category of new leaders (Labana, L.A., et al., 2006).

Engaged in the war in the DRC, in a military coalition in support of a rebellion against the Congolese government, the Ugandan and Rwandan armies finally opposed to control certain Congolese territories. This "brothers" war is the translation of the struggle for regional leadership. This is how there will be the geopolitical Redial. Between April and July 1994, the Civil war in Rwanda degenerated into the genocide of the Tutsi and Hutu of the opposition. An influx of fugitives and refugees (more than 1 million people) have found refuge in refugee camps in northern and southern Kivu, east of the DRC and at the gates of Rwanda.

Among these fugitives were militias and members of the former army, involved in the genocide and posing a threat to Rwanda. The dismantling of these camps and the dispersal of these populations has helped to weaken the balances and to generalize the insecurity in the east of the DRC. The civil war, then regional, which erupted in DRC opposed a rebellion and the Congolese army, both supported by two coalitions of foreign armies.

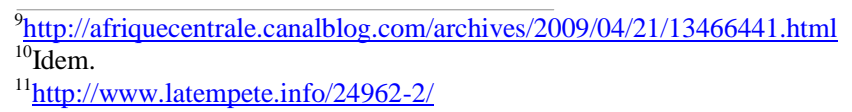


A total of ten African countries were either directly or indirectly involved in the conflict. But beyond this war, new geopolitics was emerging from Rwanda where the new power, made up of former refugees and rebels from Uganda, was Anglophone. By its influence, Rwanda switched to "Anglophone". The war in the east of the DRC was then analyzed as an attempt to topple the francophone DRC towards the Anglophone influence. In addition, it is the control of natural resources (wood and ores) of this part of the DRC (Op. cit., 2006).

The Democratic Republic of the Congo today would be different from the Republic of Zaire from the subcontracting of the American Domino in the context of the Cold War in central and southern Africa. The DRC for the period of global governance is now receiving its geopolitical identity and its strategic missions from the Nairobi Pact of the International Conference for the Great Lakes region. This is a very important strategic mutation designed to mark a turning point.

The contrast with the past of the Second Republic is striking: Yesterday, mindful of its self-determined African vocation, the DRC maneuvering and wove its network of alliances to preserve its freedom from maneuvers and exercised its right of initiative in the field of foreign policy and regional integration policy. It will be remembered its diplomatic stowage to the West despite its regional anchorage in Central Africa and the Great Lakes region and its international anchorage in the Movement of Non-Aligned Countries and in the institutional Pan-Africanism.

The examination of internal and external causes leads us to see to what extent we could adopt important strategies of stabilization within the political and administrative institutions in the Democratic Republic of the Congo.

\subsection{Institutional Stabilisation Strategies}

We have analyzed the instability of political institutions, without asking ourselves how we can try to remedy this sad situation. That is why we are dedicating this point to the strategies likely to stabilize the Institutions in the Democratic Republic of the Congo. Considerations on the causes due to inadequate constitutions based on the principles of parliamentary Democracy show us the failure of liberal or parliamentary democracy in the Democratic Republic of the Congo.

The experience of democracy is all the more valuable when it has gone through the ordeal of adversity, that is, turbulent, articulated on men, ideas and alternatives of policies. So it is of infinite richness for the greatness of man, of the state and of its population.

The pillars of democracy consolidation are:

- Unity between the Congolese;

- Building powerful lobbying to advocate for the interests of the DRC;

- The establishment of a flexible, intelligent and strategic policy of renegotiating with the West;

- The establishment of good governance and a good distribution of wealth;

- Ending impunity, etc. 
Speaking of the difficult situation prevailing in Africa, Dumont, R. (1996, 203) [24] writes: A democracy in Europe could only be reasonably envisaged after the generalization of elementary education, once a minimum of Economic development" Dumont insists on education, but we focus on the lack of democratic traditions. We need to devote ourselves to changing the mindset of people little by little.

Tackling change in mentality is a real challenge. Indeed, in order to increase the way people participate by broadening the material basis of power, the emergence of the role of independent civil society at all levels are strategies to promote democracy. In order to do this, the institutional solutions must be the following:

$\checkmark$ The restoration of the authority of the state;

$\checkmark$ Strengthening institutions;

$\checkmark$ The definition of a broad national consensus in the Constitution.

Adjustments for overall political management in a democracy must be carried out through a laborious process of negotiation between various actors. This will build a democracy without illusions and dynamics in the light of the roles played by the different social institutions.

In fact, liberal democracy is not easy to enforce. The example of England, a parliamentary country par excellence, shows us that it takes years and sometimes hundreds of years to come to parliamentary democracy. The time is taken by Western countries such as England, France, and the Netherlands, to have a head of state that reigns but does not govern shows how long and difficult the way leading to liberal or parliamentary democracy.

Moreover, democracy implies a high economic development, thus stresses Myrdal, Yunnar (1961, 30) [25] who, expressing reservations about the desirability of establishing democracy in India, reminded the Indian Parliament in 1958 that "Europe had not achieved its Various forms of democracy that after reaching an already high degree of economic development, and India's attempt to install an analogous type of democracy before a rather pronounced start of development, seemed to him to be very risky".

Buchman, J. (1962, 35), referring to the discrepancy between the political forms adopted and the economic and psychological infrastructure in the Democratic Republic of the Congo, abounds in the same sense as MYRDAL: "The new Independent states began by adopting Political Institutions close to those already implemented in their various metropolises or in other technically advanced countries.

But we have to realize that the European political Institutions have been established in regions where economic society and cultural development provide solid support for liberal democracy, the play of pluralism Ideological and partisan, to the dialogue between the Executive and the parliament. In the Negro-African countries, it is not at all the same, and genuine independence again implies a difficult and full of pitfalls of adaptation.

Therefore, black Africa would have to apply democracy in stages. The presidential regime would be the best way to enjoy the powers that are strong enough. At 
the same time, a genuine separation of powers will be put in place to begin to familiarize public opinion with the mechanisms of democracy. But it is necessary to want to apply liberal democracy at all costs. We are saying that we need to devote ourselves to changing the current political class because the Republic needs the ideal people and not the political conveniences that we are currently living.

In turn, the current economic situation depends first of all on the awareness of the Congolese decision-makers, of being able to give good directives, economic policies, agricultural policy and decentralization of it.

Finally, we can add that democracy has been introduced in the country to stimulate partisan engagement. It is reinforced by the ever-growing poverty in Congolese society. Thus, as violence forced upon submission, fortune, not only corrupts consciousness but also and above all, buys political and administrative consent. This is how the politicians of the majority (the power) and the opposition are not the same facets.

They must have one main objective of saving the country (Congo) while having an awareness of the integrity for the future of their country, the Democratic Republic of the Congo, in order to offer the Congolese people full development, real opportunities and interesting prospects because the policy of the belly, in other words, material and/or financial stakes, is not the least. The stakes and the games of the actors crystallize around the monetary interests.

Among the causes of the instability of political and administrative Institutions, we have also reported ethnic heterogeneity as well as foreign policy. It cannot be jammed:

First, we must, do everything possible to avoid the tribal struggles that can endanger the Institutions.

To this end, people should be taught the meaning of nationalism and patriotism that allows them to see beyond their tribes and to experience the satisfaction of belonging to a larger ensemble.

Kalindye, B., (2003, 66) [26], uses the positive-connotation term that suggests the idea of liberation, the disappearance of colonial oppression. To participate in the management of public affairs and the orientation of the actions and ideas of his country, this shows an honorable civic behavior. But political participation is fully realized only if it is based on a profound and valid sentiment that the nation manifests. Thus, the principle of openness to the world has given the possibility to the States of the world to come into contact with the DRC without taking into account their political system or their ideological opinion. This principle has enabled the DRC to participate actively in the international forums of the United Nations. It is the principle of the open door.

Secondly, the DRC's foreign policy must aim first in its aims at the search for regional power, security, national sovereignty, the increase of the country's economic prosperity, and the promotion of national unity. These objectives will have to lead Congolese diplomacy to promote national stability and promote peace with its neighboring countries (Labana. L.A., et al., 2006, p. 112). 
However, the difficulties of implementing the DRC's foreign policy are manifested in the fact that the DRC has not experienced a rational application in its traditional principles because of several factors which block its administration. They are of a political, cooperative and administrative nature.

As for the politicization of the Administration, the solutions reside at the level of the rational use of the frameworks available. It is necessary, as a passage says: "This is the man who must be in the right place." In such a system, public administration, an instrument and an important cog in state power, must be conceived as a State administration and not the other way around, with a mode of operation in favor of development (services to the population) instead to be a mad machine anti-population, messy rather than order.

In terms of the economy, the Congo has long been led by institutionalized predation systems. So it is a whole political economy that underlies the management system and the practices based on the method of picking: We will gather in the coffers of the state (treasury, State companies, material resources, and natural resources) in short, the plundering of the public heritage as one gathers in nature.

As you can see, we must strive to develop and improve the living conditions of the people so that the socio-economic situation can no longer provoke the instability of the institutions, since the DRC is a key player in African integration and it appropriately describes the economic issues. Thus, the development of the economy must aim, as far as possible, at economic independence to rule out influence and also to suspend the macroeconomic system which does not facilitate the emergence of the population.

Finally, we must put a point on the bad governance and the untold suffering of the population and the particularism which makes reading both appealing and informative. Thus, the misery that has become the daily lot of the Congolese population deprived of the emotional enjoyment of social and economic rights. Besides, the people must learn to sanction their political leaders by "a vote sanction", the people must come out to protest against all political policies carried out by governments. They would have to feel a threat to change things. We must have a mechanism to control government action other than Parliament's because in Parliament it is always the same majority as the government that has the wind in its stern.

To this end, the Catholic Church today calls for the full implementation of the agreement of 31 December 2016 to be respected because it has found the political description. Let's add to this that we need to focus on the debate on the full development of the Congo instead of distracting people.

Second, the potential foreign pressures are indispensable to reverse existing political structures and institutions. All these solutions are not easy to put into execution, but thinking about it would already take a step forward for a change.

\section{Conclusions}

The quick overview of "the instability of political and administrative institutions 
in the Democratic Republic of the Congo" shows us that this instability comes first and foremost from the inadequate constitutional provisions, the difficulties what causes the non-application of the democratic principles contained in the various constitutions, of ethnic heterogeneity which, from time to time, causes conflicts likely to threaten the stability of the institutions; the politicization of administration, the social-economic situation, poor governance, the non-observance of the texts and the poor distribution of wealth that most African countries in general and the DRC, in particular, are experiencing, without forgetting the influence of the macroeconomic system including foreign pressure.

Then it follows international geopolitics, the absence of powerful lobbying that negotiates well the interests of the DRC at the international level and the international policy of the predation of the wealth of the DRC which allows us to make ourselves those that promote instability in the institutions of the State. But we feel, without fear of being deceived, that they are fundamental. For this reason, we have studied institutional causes, liberal or parliamentary democracy and its consequences on the stability of institutions and we have tried to see to what extent they can be one of the factors of instability and see to what extent the influence of foreign nations, multinationals, the struggles between the great powers can undermine political stability in the countries of independent black Africa, in general, and in the Democratic Republic of the Congo, in particular.

In a context such as this, the politicization of administration promotes the imbalance and instability of political and administrative institutions. It is then that there is a cessation of activities when there is a government crisis: the administrative services are paralyzed. That is why we are experiencing the failure of liberal or parliamentary democracy in the Democratic Republic of the Congo.

Indeed, the Congolese state must come out of its current state of misfortune. As a mirror of social and economic political structures, the new state must be based on a new social contract, in short, a political consensus which must be ensured to give a legal and political meaning through a constitution. It is time to get out of our sleep and take our fate into our own hands, because we are responsible for the success or failure of our new democratic society that we wish for our best wishes.

Moreover, it is also regrettable that the macroeconomic system is introduced by the MATATA government of 2012 and the one currently in power, as well as the instability of political expediency which brings the country back to chaos, because the Republic Democratic Republic of the Congo seems to live more external budget support. The state is obliged to change the leaders of certain Institutions.

The instability of the political and administrative Institutions in the Democratic Republic of the Congo is that the crisis that the DRC experienced, more than ten years ago, originated in the conflict between the two branches of the executive in this case the presidency and the Government.

I believe that a heightened awareness on the part of the State on human rights, equality of opportunity and true social integration itself makes it easy to advance the national framework in the image of the Congolese people. The destruction of 
the administrative organic framework of the state by the clientelism, nepotism, tribalism, misappropriation, massive violations of human rights and corruption have established a new politico-administrative culture not only of predation but also of inanity in the face of evil.

In the end, the DRC is a country that cannot enforce its sovereignty, hampered by the weight of historical heritage and by regional instability. And the situation is far from being stabilized, as shown by the political crisis in which the country has been plunged since Joseph Kabila's contested re-election in November 2011. The regime's refusal to comply with the Constitution of the country and to organize the elections without the current head of State whose second and last term has expired since 19 December 2016, which prevents the improvement of the "business climate" and sometimes does not encourage Not private investment in DRC.

In short, we denounce the unspeakable suffering and misery that has become the daily lot of the Congolese population, which is deprived of the effective enjoyment of social and economic rights, due to bad governance and blatant injustice Practiced by the various Congolese governments under the beard of the institution President of the Republic.

The arbitrary use of power has prompted the people to turn away from the state or to avoid it, thereby crushing the "norms of loyalty and dignity of the country". We cannot continue to tolerate governments with limitless powers, since leaders have become accustomed to consider themselves to be above the law, by creating circles of personal supporters who are being dispensed with to ensure their silence, unable to conceal the obscure face of their management system and to ensure public control.

In the same vein as at the crossroads, the Congolese politicians of the majority (the power) and the opposition are not the same facets. Whether you are rich or poor, whether you belong to a majority or an ethnic or religious minority, whether you are opposed to or supported by the government, everyone has the right to equal protection before the law. Under no circumstances should the state impose additional inequalities. He has to treat everyone in fairness and equality. For no one is above the laws, which are in fact created by the people and are not imposed upon them.

Thus, first the political authorities must have a single main objective to save the country while having an awareness of the integrity for the future of their country, the Democratic Republic of the Congo, in order to offer the Congolese people a development Full, real opportunities and interesting perspectives.

Then we suggest that our politicians put the DRC in the circle of the 21 st century, that is, to give the people an opportunity to understand the meaning of democracy. But here the people are seen as an instrument for the promotion of politics, a simple step of the staircase. The Congolese people, in turn, must be able to distinguish between the difference between the interest of the Nation and the political sentiment towards their leaders.

All in all, we have the ambition to believe that the Democratic Republic of the 
Congo must have respect for the provisions by locking the system in the interests of consideration of democracy in the DRC. On the other hand, political leaders of any tendency must put together to eradicate these scourges. This is how they must strive to develop and improve the living conditions of the population so that the socio-economic situation can no longer provoke the instability of the institutions.

\section{Acknowledgements}

We acknowledge Prof. Dieudonne Iyeli Katamu of UPN (Universite Pegagogique Nationale) for his constructive feedback on improving earlier drafts of this paper.

\section{Conflicts of Interest}

The authors declare no conflicts of interest regarding the publication of this paper.

\section{References}

[1] Bwendelele, A. (1968) La RDC et les relations extérieures, éd. Aden, Bruxelles.

[2] Willame, J.C. (2007) Les "Faiseurs de Paix" au Congo, éd. GRIP, Bruxelles, 5-18.

[3] PNUD. (2004) 5e Forum sur la gouvernance en Afrique, cadre conceptuel, Rapport, Janvier 2002.

[4] Kibanda, M., et al. (2005) Quelle démocratie pour le Congo d'aujourd'hui ? In Revue N01de Programme d'éducation civique, 2005, 1-60.

[5] Moulin, L.S., et al. (2003) La perception de la démocratie et de l'Etat de droit en RDC. CEPAS, Kinshasa, 12-36.

[6] Tixier, G. (1966) Les causes des coups d'Etat militaires en Afrique de l'Ouest, in Revue de Droit Public, P.U.Z: Kinshasa.

[7] Minh, T.V. (1964) Réflexion sur la démocratie libérale en Asie, in Revue Juridique et Politique, Avril-Juin, P.U.Z., Kinshasa, 2-13.

[8] Gazier, F. (1961) Les Problèmes spécifiques de l'administration publique en pays sous-développés, in Civilisations, Bruxelles, 140-155.

[9] Buchman, J.L. (1962) Afrique noire Indépendante. Karthala, Paris.

[10] Benoit, J. (1981) Droit Constitutionnel et Institutions politiques. Mémento Dalloz, Paris.

[11] Senghor, L.S. (1962) Nation et voie africaine du socialisme. L'Harmattan, Paris.

[12] Campenhoudt, L. (1995) Manuel de recherche en Sciences Sociales. 2ème édition, Dunod, Paris.

[13] Bethume. (2008) Politique agricole (prospection et enjeux), éd. Futuribles, Bruxelles.

[14] Tollens, P. (2009) Les défis: Sécurité alimentaire et cultures de rente pour l'exploitation. Principales orientations et avantages comparatifs de l'agriculture en RDC, éd. Bruyland, Bruxelles.

[15] Ministère de l'agriculture. (2009) Code agricole. Kinshasa.

[16] Wembi, A. (1980) Le problème de la sous-administration dans les pays d'Afrique Noire Indépendante, in Cahiers Economiques et Sociaux, P.U.Z. Kinshasa.

[17] La Constitution de la République Démocratique du Congo (2006) Journal Officiel de la République, 47eme année, 18 février 2006 numéro Spécial. Kinshasa, 1-78.

[18] Lacoste, J.Y. (1986) La question étrangère du développement de l'Afrique. Presses de l'Université Québec, Québec.

[19] Global Witness (2005) La paix sous tension dangereux et illicite commerce de cassitérite dans l'Est de la RDC. Rapport, 16-25.

[20] Rapport de la Commission économique pour l'Afrique des Nations Unies, 2015.

[21] Ritjens, F. (2012) La grande guerre africaine, instabilité, violence et déclin de l'Etat 
en Afrique centrale, Paris, Les Belles Lettres.

[22] Labana, L.A. and Lofembe, B. (2006) La politique étrangère de la RDC, structures, fonctionnement et manifestations, Kinshasa, éd. SIRIUS.

[23] Conférence Episcopale du Congo CENCO/CARTEC, Manuel de référence d'éducation civique et électorale, 2004.

[24] Dumont, R.L. (1966) Afrique noire est mal partie. Du Seuil, Bruxelles.

[25] Myrdal, Y. (1961) De la Dictature. L'Harmattan, Paris.

[26] Kalidye, B.D. (2003) Civisme, développement et droit de l'homme. Institut Africain de droit et de la démocratie, Kinshasa. 